\title{
Download
}

UDC: 338.482:316.774:004.774.6-057.68(045) https://doi.org/10.17721/2308-135X.2021.61.22 $\underline{-28}$

Dolynska Olesya Olehivna, Doctor Of Philosophy, Associate Professor Khmelnytskyi Humanitarian and Pedagogical Academy, Khmelnytskyi, Ukraine, e-mail: dolynskyi@ukr.net

\section{APPLICATION OF SOCIAL INTERNET NETWORKS AND INTERNET BLOGS IN PROFESSIONAL TRAINING OF FUTURE TOURISTS}

The aim of the study is a practical analysis of social network services as a place to store multimedia resources that allow you to store and share digital photos, audio and video recordings, text files, presentations, and organize resource discussions for free. They can be used as educational materials (educational videos, photos on various topics, audio and video recordings of scientists' speeches, eyewitnesses of events, etc.), as well as means to store student video, photo, audio files and creative works.

Method. Theoretical materials of the research are the best practices of foreign and domestic scientists in the field of network communications and their impact on the future specialists preparing in geography and tourism, namely articles, monographs, abstracts, dissertations. The study uses the method of theoretical materials analysis, as well as methods of observation, abstraction in identifying the qualification characteristics of social Internet networks. Content analysis (analysis of the social networks community messages content); statistical and comparative information analysis was carried out. Empirical research on the social Internet networks lies in creating and filling a community on the social Internet network, as well as engaging students in that community.

Results. In the research it was found out that social networks can be used to solve the following tasks: to organize the collective work of students in the classroom (and outside it), which will be favourable to the communication, to gain the team experience; to ensure the development of 
the students personalized learning environment; to promote students independent learning, as everyone works in his own rhythm; to promote informal communication between the tutor and the students; to change the tutor's role, who will become an assistant, friend, mentor; to create digital educational content of the disciplines.

The scientific novelty of the obtained results lies in the fact that on the comprehensive analysis of social internet networks, internet blogs, tourist internet resources basis, their place and role in the information and educational environment of higher education institutions are determined, in particular: the specifics of the content, prospects and mechanisms of the development of the social Internet networks from the point of view of training future tourists are determined; the dependence of the functions of the Social Internet Network, Internet blogs on their structural elements is established.

Practical significance. The obtained scientific results are used in the educational process of future specialists in the field of training "Tourism", with the educational qualification "tourism expert, organizer of excursion and animation activities" when teaching the disciplines "study of local lore and tourism", "tourist work", "recreational geography", "geography of Ukraine", "professional competencies in tourism business", "organization of tourist activities". The research practices can be used to conduct tourist, museum, local history, excursion and other types of student's practice.

Keywords: professional training of future tourists, social internet networks, internet blogs, tourist internet resources.

\section{References}

1. Ahmedova A. T., Betretdinova I. A. Integratsiya sotsialnyih setey v protsess obucheniya. Molodezhnyiy nauchnyiy forum. Gumanitarnyie nauki : elektron. sb. st. po materialam VI stud. mezhdunar. zaoch. nauch.-prakt. konf. Moskva : MTsNO. 2013. \# 6 (6). URL:

https://nauchforum.ru/archive/MNF_humanities/6(6).pdf (data obrascheniya: 18.02.2021).

2. Vykorystannia sotsialnykh merezh u navchalnykh tsiliakh. Studentskyi portal. UaStudent.com. URL: http://uastudent.com/vykorystannja-socialnyh-merezh-u-navchalnyh-ciljah (data zvernennia: 10.03.2021). 
3. Gostev V. M., Mihaylov V. Yu. Informatsionno-kommunikatsionnyie tehnologii v realizatsii sovremennyih pedagogicheskih metodik : ucheb.-metod. posob. po napravleniyu «Elektronnyie obrazovatelnyie resursyi». Kazan, 2008. $35 \mathrm{~s}$.

4. Kolii O. S. Stan ta tendentsii vprovadzhennia internet-tekhnolohii, yak orhanizatsii navchalnoi vzaiemodii. Problemy intehratsii pryrodnychykh, tekhniko-tekhnolohichnykh ta humanitarnykh dystsyplin v pidhotovtsi fakhivtsiv u VNZ : materialy Vseukr. nauk.-metod. Internet-konf. (m. Kharkiv, 2017 r.). S. 163-164. URL:

https://docplayer.net/83061935-Ministerstvo-osviti-i-nauki-ukrayini.html (data zvernennia: 20.02.2021).

5. Konevshchynska O. E. Rozvytok poniattia informatsiino-osvitnoho seredovyshcha navchannia starshoklasnykiv $v$ aspekti vykorystannia sotsialnykh elektronnykh merezh. Informatsiini tekhnolohii i zasoby navchannia. 2015. T. 45, \# 1. S. 12-20. URL: http://eprints.zu.edu.ua/22400/2/\%D1\%81\%D1\%82\%D0\% B0\%D1\%82\%D1\%82\%D1\%8F\%20\%E2\%84\%961\%20\%2845\%29\%202015.pdf (data zvernennia: 09.03.2021).

6. Kudryavtseva I. A. Obrazovatelnyiy blog v deyatelnosti uchitelya-predmetnika. Teoriya i praktika obrazovaniya $v$ sovremennom mire : materialyi Mezhdunar. nauch. konf. (g. Sankt-Peterburg, fevral 2012 g.). Sankt-Peterburg : Renome, 2012. S. 408-410.

7. Lyichkovskaya O. R. Diskurs kommunikativnyih praktik sotsialnyih media (na primere analiza Twitter). Visnyk Odeskoho natsionalnoho universitetu. Sotsiologiia i politychni nauky. 2013. T. 18. Vip. 2 (1). S. 340-352. URL: http://nbuv.gov.ua/UJRN/Vonu_sip_2013_18_2(1)_37 (data obrascheniya: 09.03.2021).

8. Novyie trendyi v obrazovanii. Blogi, vebinaryi, sotsialnyie seti. URL: http://itmultimedia.ru/novye-trendy-v-obrazovanii-blogi-vebinary-socialnye-seti-i-dr/ (data obrascheniya: 21.03.2021).

9. Ocadchyi V. V. Systema informatsiino-tehnolohichnoho zabezpechennia profeciinoi 
pidhotovky maibutnix uchyteliv $v$ umovax pedahohichnoho univepcytetu : dyc. ... d-pa ped. nauk :13.00.04. Vinnytsia, 2013. S. 315.

10. Osadchyi V. V. Vykorystannia zasobiv internet u profesiinii pidhotovtsi vchytelia. Molod $\mathrm{i}$ rynok : shchomisiach. nauk.-ped. zhurn. 2013. \# 12 (107). S. 32-37. URL:

http://mr.dspu.edu.ua/publications/2013/12_107_2013.pdf (data zvernennia: 27.02.2021).

11. Osadchyi V. V. Sotsialni internet-merezhi yak zasib dystantsiinoho navchannia. Visnyk pisliadyplomnoi osvity : zb. nauk. pr. Kyiv, 2012. Vyp. 7. S. 167-173.

12. Patarakin E. D. Setevyie soobschestva i obuchenie. Moskva : PER-SE, 2006. 112 s.

13. Slovnyk internet-terminiv. URL: http://prodecide.com.ua/uk/ dictionary.html (data zvernennia: 11.03.2021).

14. Tyshko V. O., Parshukov S. V. Rol sotsialnykh merezh u navchalnomu protsesi. URL: http://informatika.udpu.org.ua/?page_id=1207 (data zvernennia: 21.02.2021).

15. Fisenko T. V. Doslidzhennia sotsialnykh internet-merezh u pratsiakh zarubizhnykh vchenykh u 1930-2000 rr.: komunikatyvnyi vymir. URL: http://oldconf.neasmo.org.ua/node/682 (data zvernennia: 02.03.2021).

16. Fisenko T. V. Sotsialni internet-merezhi yak fenomen suchasnoho media-seredovyshcha : dys. ... kand. nauk iz sotsialnykh komunikatsii : 27.00.07. Kyiv, 2012. $210 \mathrm{~s}$.

17. Barnes J. A. Class and committees in a Norwegian island parish. URL: http://garfield.library.upenn.edu/classics1987/A1987H444400001.pdf (last accessed: 21.02.2021) 
18. Gurak L., Antonijevic S. The Psychology of Blogging: You, Me, and Everyone in Between. American Behavioral Scientist. 2008. Vol. 52. N. 8. P. 60-68. 